\title{
Paleogeography and stratigraphy of Placoparia and "odontochilinid" trilobites
}

Paleobiological working paper

\section{Oldřich Fatka $^{1}$, Petr Budil ${ }^{2}$, Jan Toman ${ }^{3}$}

1: Institute of Geology and Palaeontology, Faculty of Sciences, Charles University

2: Czech Geological Survey

3: Department of Philosophy and History of Sciences, Faculty of Sciences, Charles University 
Palaeogeographical distribution of four species of Placoparia in Ordovician

(map adapted from Fatka and Mergl, 2009)

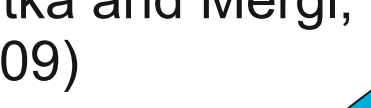




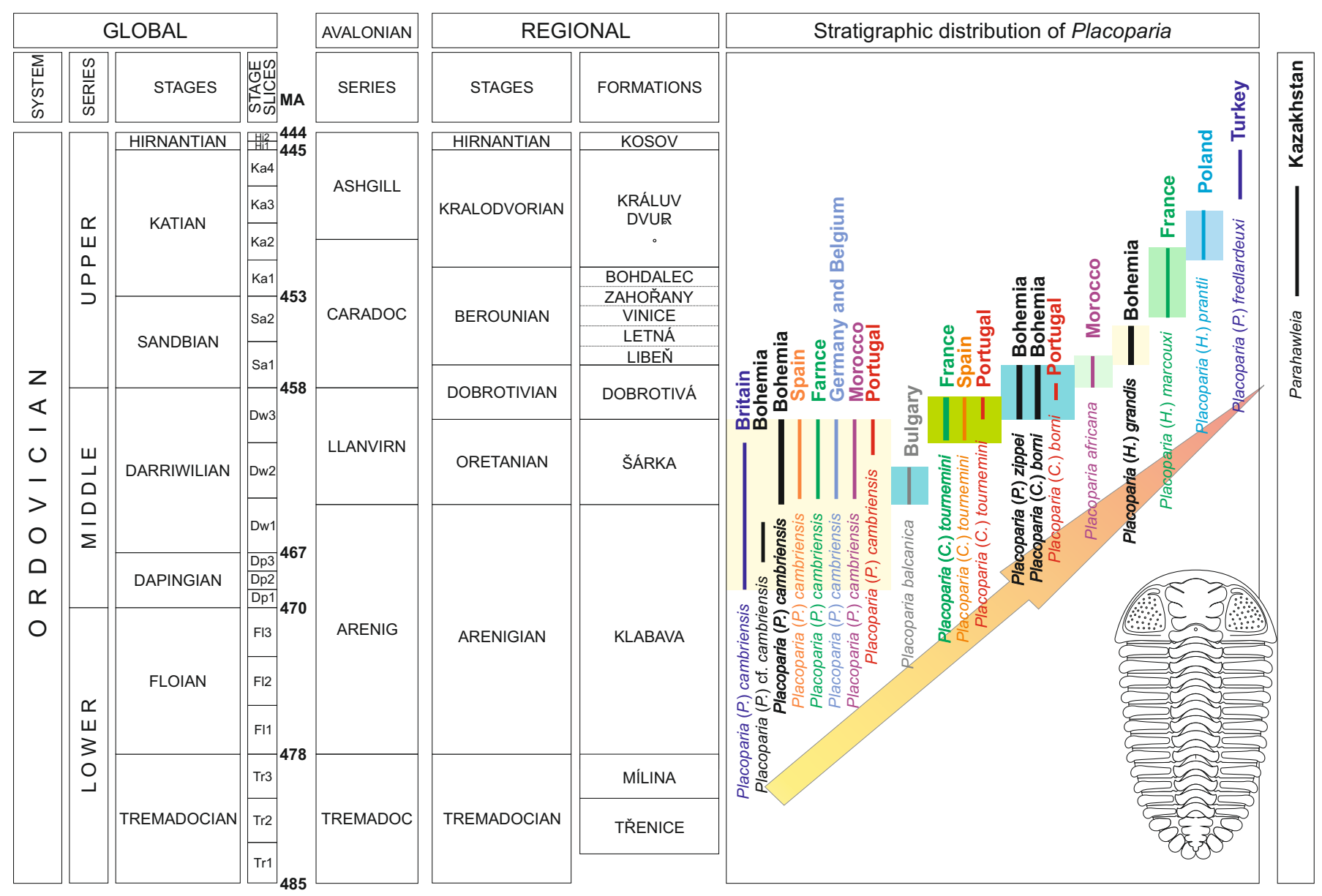


Palaeogeographical distribution of ,odontochilinid' trilobites in Lower Devonian (map adapted from Budil et al., 2014)

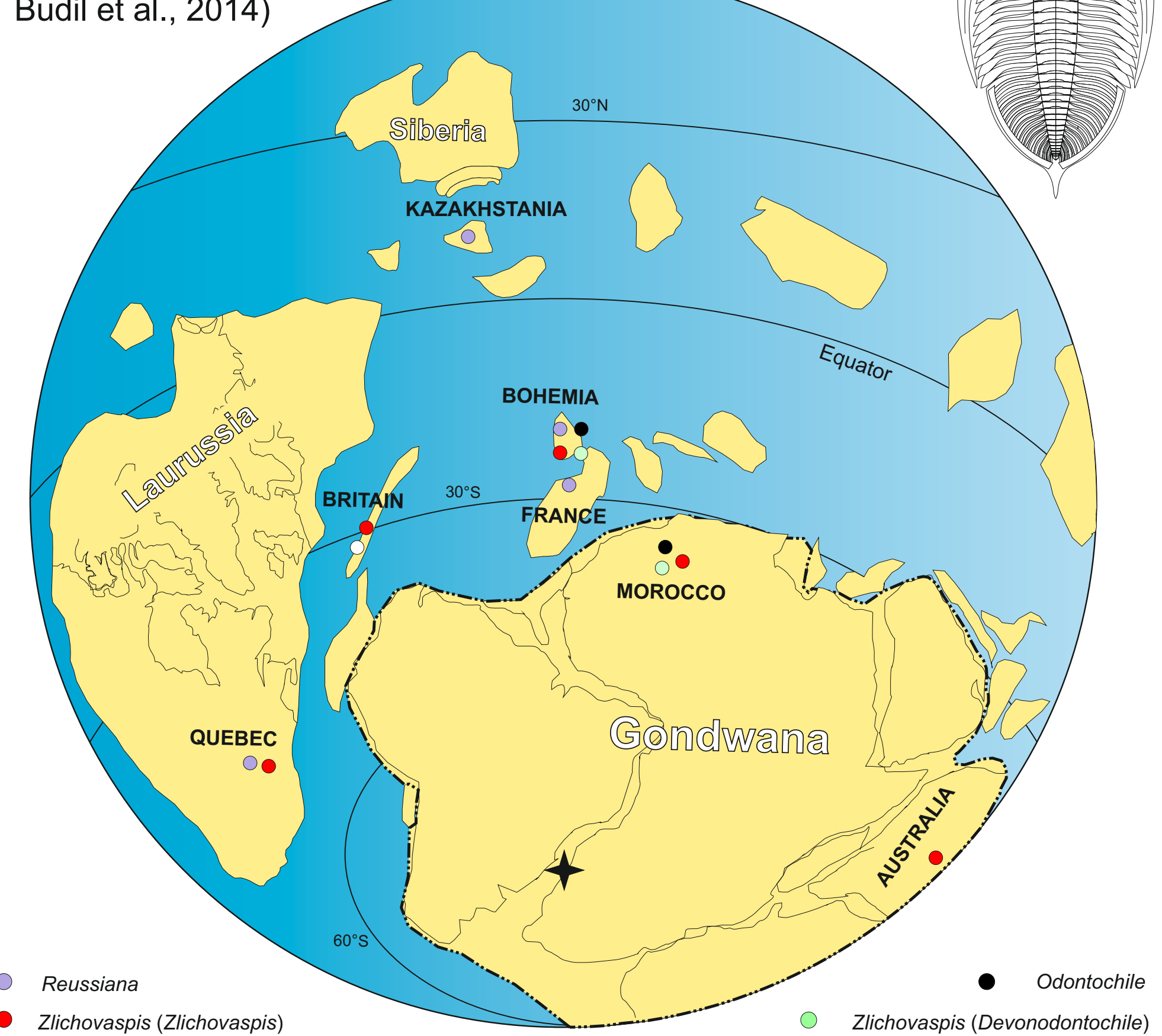




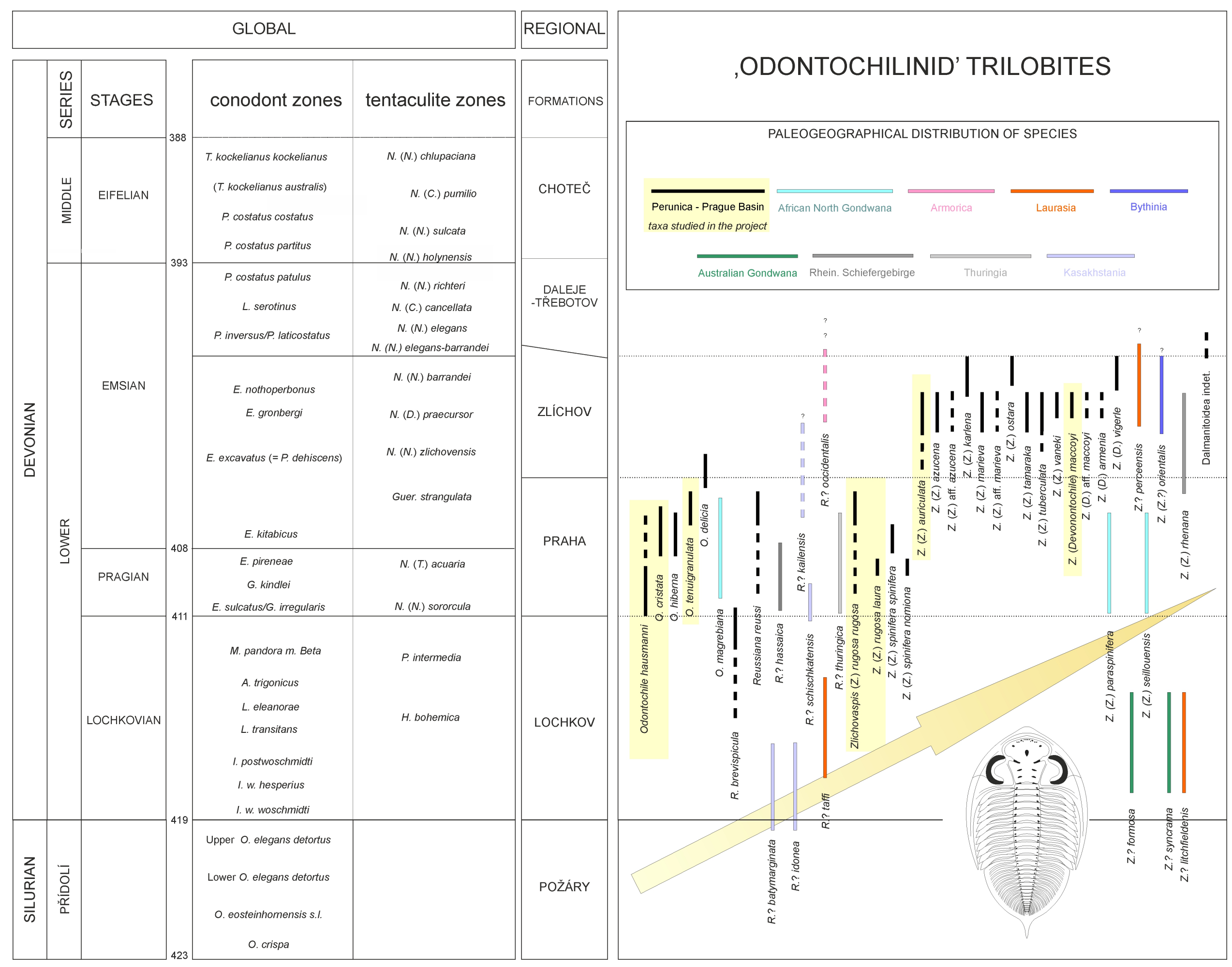




\section{References}

Budil P, Fatka O, Rak Š, Hórbinger F. 2014. Unusual occurrence of dalmanitid trilobites in the Lochkovian (Lower Devonian) of the Prague Basin, Czech Republic. Bull. Geosci. 89: 325334.

Fatka O, Mergl M. 2009. The 'microcontinent' Perunica: status and story 15 years after conception. In: Bassett MG, ed. Early Palaeozoic peri-Gondwana terranes: new insights from tectonics and biogeography. Geological Society, London, Special Publications 325: 65-101. 